\title{
Revision External Dacryocystorhinostomy Results After a Failed Dacryocystorhinostomy Surgery
}

Emine Akcay · Nilay Yuksel · Umut Ozen

Received: February 3, 2016/Published online: April 13, 2016

(C) The Author(s) 2016. This article is published with open access at Springerlink.com

\begin{abstract}
Objective: To report revision external dacryocystorhinostomy (rE-DCR) results following failed dacryocystorhinostomy (DCR) surgery.
\end{abstract}

Methods: A retrospective review of patients who underwent rE-DCR between June 2006 and June 2015 at Yildırım Beyazıt University Ankara Ataturk Training and Research Hospital Department of Ophthalmology. Data were collected on the primary surgery technique and patient demographics.

Results: Forty-one rE-DCRs were performed on 40 patients after various failed DCR techniques. Two patients had failed DCR twice, and 38 patients had failed DCR once. Six of these previous failed DCRs were multidiode laser DCR, two of them were endoscopic DCR, and 33 were external dacryocystorhinostomy (E-DCR). In all rE-DCR procedures, silicone

Enhanced content To view enhanced content for this article, go to http://www.medengine.com/Redeem/ F3B4F060519688E0.

E. Akcay · N. Yuksel · U. Ozen $(\bowtie)$

Department of Ophthalmology, Yildirim Beyazit

University, Ankara Ataturk Education and Research

Hospital, Bilkent, Ankara, Turkey

e-mail: drumutozenn@hotmail.com tube intubation was performed, and the tube was removed at least 6 months after surgery. We used mitomycin C on 16 patients (40\%). At the last examination, six patients still had epiphora (15\%), and their nasolacrimal passage was obstructed. Thirty-four patients had no complaints, and their passages were open (85\%).

Conclusion: The rE-DCR procedure has high success rates for failed DCR surgeries, whichever procedure was performed.

Keywords: External dacryocystorhinostomy; Failed dacryocystorhinostomy; Mitomycin C; Revision external dacryocystorhinostomy

\section{INTRODUCTION}

E-DCR is a widely acceptable and common surgical procedure for primary acquired nasolacrimal duct obstruction in which a communication between the lacrimal sac mucosa and nasal mucosa is created [1]. Because E-DCR has disadvantages such as leaving incision scars, more noninvasive surgical procedures have been developed. Despite the advantages of multidiode laser 
DCR or endoscopic DCR, such as no incision scarring or less hemorrhaging during the procedure, E-DCR failures are less frequent than those of these techniques [2, 3]. Some studies in the literature report failed E-DCR rates of $5-10 \%$ [4-6] to $35-40 \%$ [7-9]. E-DCR is usually preferred for the treatment of failed DCRs. In this study we aimed to report our rE-DCR results after various failed DCR surgeries.

\section{METHODS}

From June 2006 to June 2015 at Yıldırım Beyazıt University Ankara Ataturk Training and Research Hospital Department of Ophthalmology, a total of 41 eyes of 40 patients who underwent rE-DCR procedures performed after failed DCRs were gathered from the department files, retrospectively. All patients were operated on by the same surgeon under general anesthesia. All patients were suffering from epiphora. There was no trauma history in any of the patients before the epiphora occurred and no ocular abnormalities. Preoperatively, after a standard ocular examination including visual acuity, biomicroscopic anterior segment and fundus examination, to confirm nasolacrimal duct obstruction, nasolacrimal duct irrigation was done, and blocked syringing was seen in all 40 patients. All patients consulted an ear, nose and throat (ENT) specialist to detect any nasal pathology. Especially if a nasal septum deviation on the same side as our surgical area was reported by the ENT specialist, we postponed our rE-DCR surgery until the patient had undergone nasal septum surgery because a nasal septum deviation blocking the inferior nasal concha and Hasner valve would make our surgery more difficult.

A J-shaped skin incision was made with a surgical knife over the sac area. The periosteum overlying the lacrimal fossa and the area above were elevated with a periosteum elevator. If the bone osteotomy size was insufficient, smaller than $10 \times 10 \mathrm{~mm}$, it was expanded with a Kerrison punch. The lacrimal sac was opened in a longitudinal fashion to form anterior and posterior lacrimal flaps unless it had not been opened before. If the failed DCR surgery was an E-DCR, it was obviously harder to recreate flaps than for the other failed DCR techniques because of the existence of granulation and fibrotic tissue. Lacrimal sac mucosa and nasal mucosa were fashioned in an $\mathrm{H}$ shape, respectively. After controlling hemorrhaging, anterior and posterior mucosal flaps were sutured using 6.0 vicryl, and all patients were silicone intubated. The subcutaneous tissue and skin were then sutured using 6.0 vicryl in a continuous fashion. Mitomycin C was used particularly in patients who had excessive granulation tissue at the surgical area, especially surrounding the sac and previous flaps; $0.02 \% \mathrm{mg} / \mathrm{ml}$ mitomycin C was used between the flaps with a surgical sponge saturated with the drug for approximately $2 \mathrm{~min}$ and then irrigated. A nasal pack with antibiotic ointment was placed at the end of the surgery. After $24 \mathrm{~h}$, the nasal pack was removed, and syringing was done from the lower punctum to check the patency of the lacrimal passage. Postoperatively, patients were given amoxicillin-clavulanate and naproxen sodium tablets twice a day for 7 days and local netilmicin-dexamethasone and ketorolac eye drops for 2 weeks. The skin sutures were removed after 7 days. The silicone tube was removed at least after 6 months. The patients were followed up at the 1st week and 1, 3, 6 and 12 months. The patients who were followed up less than 3 months were excluded. Successful rE-DCR was defined as relief of symptoms and an open passage at nasolacrimal syringing. All 
procedures followed were in accordance with the ethical standards of the responsible committee on human experimentation (institutional and national) and with the Helsinki Declaration of 1964, as revised in 2013. Informed consent was obtained from all patients for being included in the study.

\section{Statistical Analysis}

We used Windows SPSS version 16.0 and descriptive statistics to evaluate our surgical outcomes and to calculate our mean values.

\section{RESULTS}

The mean age was $48.95 \pm 12.59$ years (range 19-69). There were 31 females (77.5\%) and 9 males $(22.5 \%)$. Two of our patients underwent failed DCR twice, and 38 patients underwent failed DCR once. Six of these previous failed DCRs were multidiode laser DCRs (14.6\%), 2 were endoscopic DCRs (4.8\%), and 33 were external DCRs (80.4\%). Three of these 41 failed surgeries had taken place in our clinic before, and all of these failed DCR surgeries were E-DCRs. The mean time was $76.4 \pm 107.7$ months (range 1-420 months) between the previous failed DCR and our rE-DCR. The mean time for epiphora compliant recurrence after failed DCR was $2.39 \pm 1.40$ months (range 1-6 months). After rE-DCR, the mean follow-up time was $38.9 \pm 35.7$ months (range 3-67 months). The mean silicone tube removal time was $6.2 \pm 1.06$ months (range 6-12 months).

Among 33 failed E-DCR surgeries, we detected excessive granulation tissue in $85 \%$ of the patients during the surgery. Also among eight failed multidiode laser and endoscopic DCR surgeries, we detected inadequate osteotomy sites $(<10 \times 10 \mathrm{~mm})$ in $83 \%$ of the patients during surgery.
One of our patients who underwent failed DCR twice had E-DCR surgery, and the other patient underwent laser DCR twice and failed both. At the last examination after revision surgery, the patient who had two failed E-DCR surgeries had a blocked nasolacrimal duct passage. Intraoperatively, there was excessive granulation tissue. However, the patient who had two failed multidiode laser DCR surgeries, who had an inadequate osteotomy site intraoperatively, now has an opened nasolacrimal passage and no complaints.

At the last examination, six patients still had epiphora (15\%) and were blocked when using the syringing nasolacrimal apparatus. Five of these patients were female and one male. Three of our patients' epiphora complaints continued just after our rE-DCR surgery, and the other three patients' complaints recurred 1 month after the rE-DCR surgery. Five of these patients' previous surgeries were E-DCRs, and one patient had endoscopic DCR surgery. We used 0.02\% mitomycin $\mathrm{C}$ on four of these six patients because of excessive granulation tissue at the operation site. Thirty-four patients had no complaints, and their passages were open. The overall success rate was $85 \%$ (Table 1 ).

\section{DISCUSSION}

In this series of 41 failed DCRs, reoperation using the rE-DCR technique had an $85 \%$ success

Table 1 Our rE-DCR Success Rates

\begin{tabular}{lcc}
\hline $\begin{array}{l}\text { Failed DCR } \\
\text { procedures }\end{array}$ & $\begin{array}{l}\text { Number of } \\
\text { patients }\end{array}$ & $\begin{array}{l}\text { Success rate at } \\
\text { final examination } \\
\text { (after rE-DCR) }\end{array}$ \\
\hline Endoscopic DCR & 2 & $1(\% 50)$ \\
Laser DCR & 6 & $6(\% 100)$ \\
External DCR & 33 & $28(\% 84)$ \\
All DCR techniques & 41 & $35(\% 85)$ \\
\hline
\end{tabular}


rate. Ari et al. evaluated their 14 months of follow-up results of rE-DCR surgeries and reported $85 \%$ anatomical success and $78 \%$ both anatomical and functional success [10]. Our success rate is compatible with that of primary operated DCRs $[1,11,12]$. It is well known that success in DCR surgery is compromised by anatomical or functional problems such as a small osteum or blockage of the osteum or canalicular system because of fibrosis [12, 13]. Intraoperatively, we observed that the reason for the failure in the previous DCR was likely not creating a proper osteum, especially for laser-assisted and endoscopic DCRs. In previous failed E-DCRs, we detected excessive granulation tissue at the operation site as the main reason for failure.

It has been shown that the success rate can be increased by using intraoperative mitomycin C, an antiproliferative agent placed over the anastomized posterior flaps and osteotomy site [13]. In our study, we used mitomycin C in cases with excessive fibrosis and granulation tissue.

Another important point in revision cases is usage of silicone stents. Some studies report that leaving in silicone tubes for a long time may cause more granulation tissue, but some authors suggest long-term use particularly in revision cases [14-16]. Therefore, because of these studies and our clinical experiences, we left the silicone tubes in for at least 6 months after revision surgery in our cases. But it is obvious that if the patient does not return for his or her follow-up on time, the time with a silicone stent is extended unintentionally.

In different study series, the frequency of recurrent epiphora after DCR surgery is reported as $5 \%$ to $17 \%[17,18]$. The most important factors that play a role in the failure of a DCR surgery are inadequate rhinostomy, excessive scar tissue proliferation, anatomic anomalies and concomitant paranasal sinus infections [19]. There have been many surgical attempts for failed DCRs. In general, the preferred revision DCR surgeries after a failed DCR are endoscopic non-laser, multidiode laser, external or transcanalicular laser diode DCR.

Many studies have compared whether revision endoscopic or external DCR gives better results after failed DCR surgeries [18, 20]. Although recent studies report similar success rates in revision endoscopic DCR and rE-DCR, due to less scarring and providing a chance to interfere with endonasal pathologies, endoscopic revision surgeries have been praised [19-21]. It is also known that, as a disadvantage, the endoscopic DCR procedure requires more surgeon experience and more surgical tools. With the rE-DCR procedure we were able to remove the granulation tissue from the drainage site and easily expand the former and inadequate osteotomy. We think that our high success rates for rE-DCR procedures are correlated with our mitomycin $\mathrm{C}$ usage in the appropriate patients, leaving the silicone tube in for a sufficient time and removing the silicone tube at the appropriate time in all patients. Although many different DCR surgical procedures have been described, rE-DCR is likely the gold standard surgical technique after failed DCR surgery [1, 22, 23]. The retrospective nature and small patient number are the main limitations of this study; the long follow-up duration is its main strength.

\section{CONCLUSION}

Despite the new techniques in primary acquired nasolacrimal duct obstruction, external DCR is still a safe and effective surgical procedure. However, there is always a possibility of failure in all surgical procedures. For revision surgeries, usage of silicone tubes and mitomycin $\mathrm{C}$ and 
creating a proper osteum are the most important factors for a successful surgery. As a result, the rE-DCR procedure, as a highly appropriate revision surgery for failed DCRs, has a high success rate, strengthened by the usage of a silicone tube and mitomycin $\mathrm{C}$ and creation of a proper osteum.

\section{ACKNOWLEDGMENTS}

No funding or sponsorship was received for this study or publication of this article. All named authors meet the International Committee of Medical Journal Editors (ICMJE) criteria for authorship of this manuscript, take responsibility for the integrity of the work as a whole and have given final approval for the version to be published.

Disclosures. E. Akcay, N. Yuksel and U. Ozen have nothing to disclose.

Compliance with Ethics Guidelines. All procedures followed were in accordance with the ethical standards of the responsible committee on human experimentation (institutional and national) and with the Helsinki Declaration of 1964, as revised in 2013. Informed consent was obtained from all patients for being included in the study.

Open Access. This article is distributed under the terms of the Creative Commons Attribution-NonCommercial 4.0 International License (http://creativecommons.org/licenses/ by-nc/4.0/), which permits any noncommercial use, distribution, and reproduction in any medium, provided you give appropriate credit to the original author(s) and the source, provide a link to the Creative Commons license, and indicate if changes were made.

\section{REFERENCES}

1. Go Y, Park J, Kim K, Lee S. Comparison of nonlaser endoscopic endonasal revision surgery and diode laser transcanalicular revision surgery for failed dacryocystorhinostomy. J Craniofac Surg. 2015;26(3): 863-6.

2. DuVy MT. Advances in lacrimal surgery. Curr Opin Ophthalmol. 2000;11:352-6.

3. Balikoglu-Yilmaz M, Yilmaz $\mathrm{T}$, Taskin $\mathrm{U}$, et al. Prospective comparison of 3 dacryocystorhinostomy surgeries: external versus endoscopic versus transcanalicular multidiode laser. Ophthal Plast Reconstr Surg. 2015;31(1):13-8.

4. McMurray CJ, McNab AA, Selva D. Late failure of dacryocystorhinostomy. Ophthal Plast Reconstr Surg. 2011;27(2):99-101.

5. Hartikainen J, Antila J, Varpula M, Puuka P, Seppa $\mathrm{H}$, Grenman R. Prospective randomized comparison of endonasal endoscopic dacryocystorhinostomy and external dacryocystorhinostomy. Laryngoscope. 1998;108:1861-6.

6. Hartikainen J, Grenman R, Puukka P, Seppa H. Prospective randomized comparison of endonasal endoscopic dacryocystorhinostomy and external dacryocystorhinostomy. Ophthalmology. 1998; 105:1106-13.

7. Tarbet KJ, Custer PL. External dacryocystorhinostomy: surgical success, patient satisfaction and economic cost. Ophthalmology. 1995;102:1065-70.

8. Yung MW, Hardman-Lea S. Analysis of the results of surgical endoscopic dacryocystorhinostomy: effect of the level of obstruction. $\mathrm{Br} \mathrm{J}$ Ophthalmol. 2002;86(7):792-4.

9. Durvasula V, Gatland DJ. Endoscopic dacryocystorhinostomy: long-term results and evolution of surgical technique. J Laryngol Otol. 2004;118:628-32.

10. Ari S, Kürşat Cingü A, Sahin A, Gün R, Kiniş V, Caça I. Outcomes of revision external dacryocystorhinostomy and nasal intubation by bicanalicular silicone tubing under endonasal endoscopic guidance. Int J Ophthalmol. 2012;5(2):238-41.

11. Okuyucu S, Gorur H, Oksuz H, Akoglu E. Endoscopic dacryocystorhinostomy with silicone, polypropylene, and T-tube stents; randomized controlled trial of efficacy and safety. Am J Rhinol Allergy. 2015;29(1):63-8. 
12. Dalez D, Lemagne JM. Transcanalicular dacryocystorhinostomy by pulse Holmium-YAG laser. Bull Soc Belge Ophthalmol. 1996;263:139-40.

13. Sharma BR. Non endoscopic endonasal dacryocystorhinostomy versus external dacryocystorhinostomy. Kathmandu Univ Med J (KUMJ). 2008;6:437-42.

14. Mickelson SA, Kim DK, Stein IM. Endoscopic laser assisted dacryocystorhinostomy. Am J Otolaryngol. 1997;18:107-11.

15. Metson R. The endoscopic approach to revision dacryocystorhinostomy. Laryngoscope. 1990;100: 1344-7.

16. Orcutt JC, Hillel A, Weymuller EA. Endoscopic repair of failed dacryocystorhinostomy. Ophthal Plast Reconstr Surg. 1990;6:197-202.

17. Shams PN, Chen PG, Wormald PJ, et al. Management of functional epiphora in patients with an anatomically patent dacryocystorhinostomy. JAMA Ophthalmol. 2014;132(9):1127-32.

18. El-Guindy A, Dorgham A, Ghoraba M. Endoscopic revision surgery for recurrent epiphora occurring after external dacryocystorhinostomy. Ann Otol Rhinol Laryngol. 2000;109(4):425-30.
19. Korkut AY, Teker AM, Ozsutcu M, Askiner O, Gedikli O. A comparison of endonasal with external dacryocystorhinostomy in revision cases. Eur Arch Otorhinolaryngol. 2011;268:377-81.

20. Taşkıran Çömez A, Karadă̆ O, Arıkan S, Gencer B, Kara S. Comparison of transcanalicular diode laser dacryocystorhinostomy and external dacryocystorhinostomy in patients with primary acquired nasolacrimal duct obstruction. Lasers Surg Med. 2014;46(4):275-80.

21. Hong JE, Hatton MP, Leib ML, Fay AM. Endocanalicular laser dacryocystorhinostomy analysis of 118 consecutive surgeries. Ophthalmology. 2005;112:1629-33.

22. Liao SL, Kao SC, Tseng JH, Chen MS, Hou PK. Results of intra operative mitomycin $\mathrm{C}$ application in dacryocystorhinostomy. $\mathrm{Br} \mathrm{J}$ Ophthalmol. 2000;84:903-6.

23. Piaton JM, Limon S, Ounnas N, Keller P. Trans canalicular endodacryocystorhinostomy using neodymium: YAG laser. J Fr Ophthalmol. 1994;17:555-67. 